\title{
The Implementation of Ultimum Remedium Principles in Law Enforcement of Criminal Act Illegal Mining
}

\author{
Basuki \\ Doctor Legal Science Programs \\ Borobudur University \\ Jakarta, Indonesia \\ barenbastian@gmail.com
}

\begin{abstract}
The problem of illegal mining crime is a problem that is not merely a problem that can be solved criminally, but also associated with social, economic, and community environment, because the perpetrators are mostly local community groups who are marginally dependent on illegal mining, therefore becomes a crucial law enforcement problem, demanding a serious surveillance from the government in adopting a punitive punishment policy related to articles 158 and 160 of Law No.4 of 2009 on Mineral and Coal Mining.

The emerging problems in managing the handling of illegal mining cases (PETI) are the author reason to conduct a research to examine the policies that have been using criminal law enforcement approach, along with problems associated to the correlation of legal aim and benefits for the PETI community and its constraints, also appropriate policies to overcome illegal mining problems. This research uses normative juridical research method with the legislative approach and analyzed qualitatively by literature study and field observation on PETI community perpetrators of gold mining at Gunung Pongkor Bogor, and also socio-legal research method. The result has shown that it is obvious that the existence of the ultimatum remedium provides the government a space to formulate alternative policy rather than solving the problems by criminal punishment. The resolves of above problems stated, is the occurrence background factor, regulatory issues, the bureaucratic capacity, normative guidance and supervision factors, law enforcement constraint factor and socioeconomic factor.

The policy of law enforcement through utilitarianism approach and punitive policy as ultimatum remedium. In the end, it is suggested that law enforcement apparatus must consider non-punitive law enforcement towards PETI and the government should prioritize the guidance and supervision so that local communities' apparatus who are dependent marginally are forced to do PETI's deed as if it is a legal business.
\end{abstract}

Keywords-economic factors, illegal mining, ultimum remedium in law enforcement.

\section{INTRODUCTION}

The journal discussed about the issue of Unlicensed Mining (PETI) that is under criminal act of Mineral and Coal Mining field, ru led under the act of Mineral and Coal Mining (Minerba Law) articles 158 and 160 of Law No.4 of 2009 and Implementation Regulation which is regulated under Government Regulation No 23 of 2010 as amended several times and the last amendment is Government Regulation
No.77 of 2014 on Second Amendment Government Regulation No 23 of 2010. Unlicensed mining merely not a legal concern because the unlicensed mining is done by marginal group local communities and depend their life by working on unlicensed mining activities, causing problems related to many aspects, these are social aspect, economics, environment and legal aspect; therefore according to the aim of Mineral and Coal Mining management involved four main as pect related to each other and relate to the characteristic of Mineral and Coal natural resources as non-renewable resources. Management concept of Mineral and Coal mining in Indonesia implement the sustainable concept, based on conventional development emphasizes on economic growth, that resulted in negligence or social and environmental aspect failures 1, due to the reason that conventional development put mere economic targets as the central issue of growth, and puts social and environmental factors in a position that is less important, although we recognize that natural resources Mineral and Coal is a natural resource that is not renewable[1]. The non-renewed is sue of mineral resources and non-renewable resource management is also highlighted by UNEP [2] which introduces the concept of sustainable development that seeks to collaborate on economic, social, environmental and legal aspects in a concept of cumulative mineral and coal mining management based on the principle of mineral exploitation and coal is done in order to fulfill the needs of industry and energy present, and sacrifice the fulfillment of future generation's needs. Philosophically, the mineral and coal management policy in the mining jurisdiction land of Indonesian must be in accordance with article 33 paragraph 3 of the 1945 states that "The land, the waters and the natural resources within shall be under the powers of the State and shall be used to the greatest benefit of the people". As affirmation of Constitutional Court Decision [3] which in essence that State as holder of right to control.

The concept of a unified convergence between aspects of economic growth, social equity, and environmental protection in policy and implementation of the mineral and coal resources management policy contained in the Indonesian mining legal territory constitute wealth the nonrenewable nature has an important role in fulfilling the livelihood of the people should be the philosophical foundation of the management of Indonesia's natural resources, as pointed out by Drexhage and Deborah Murphy stating that "it is generally accepted that sustainable 
development call for a convergence between the three pillars of economic development, social equity, environmental protection. Sustainable development is a visionary development paradigm; and over the past 20 years governments, businesses, and civil society have accepted sustainable development as a guiding prunciple, made progress on sustainable development metrcs, and improved businesses and NGO participation in the sustainable development process. Yet the concept remains elusive and implementation has proven dificult"[4] (it is generally accepted that sustainable development requires convergence between the three pillars of economic development, social justice, environmental protection Sustainable development is a visionary paradigm, and over the past 20 years governments, businesses and civil society have accepted sustainable development as potential guides progress on sustainable development metrics, and improve business and NGO participation in sustainable development processes, but the concept remains elusive and implementation has proved difficult.)

The right of the state to control Indonesia's natural resources is translated into the authority of the government over the management of natural resources through the government's authority in granting licenses [5] or government authorities to establish licensing instruments, licenses and concessions. The authority of the government in the management of natural resources of minerals and coal is contained in Law No. 4 of 2009 on Mining and Minerals and its implementation regulation in the form of Government Regulation No. 23 of 2010 on Mineral and Coal Mining Business Activities hereinafter referred to as Government Regulation No. 23 Year 2010 as amended the last few times with Government Regulation No. 77 of 2014 on the Second Amendment to Government Regulation No. 23 of 2010, the Regulations on the authority of the government in the granting of licenses both business licenses and business territories are regulated in Articles 6, 7, 8, Article 35 to Article 63 Law No. 4 of 2009.

The regulation on government authority on licensing is also regulated in Law No. 23 of 2014 on Regional Government which regulates the authority of central government and related local government in the field of Mineral and Coal Affairs [6].

Regarding licensing authority in the MINERBA Law is divided into the authority of the central government, provincial and district / municipal governments where the authority approach is based on the administrative region approach, namely the authority of the permit by the Minister of Energy and Mineral Resources covering the authority of the location, benefits and impacts across the province while the governor's authority covers cross- / City, then the authority of Regent / Mayor is in one Regency / Municipality [7].

Detailed arrangements related to licensing requirements are regulated by Government Regulation No 23 of 2010 stipulating that Every business license in the field of Mineral and Coal Mining must meet administrative, technical, environmental and financial requirements. Regulations on business activities or mining are classified into 3 types of mining business, namely mining business permit (IUP), special mining business permit (IUPK) and people's mining permit (IPR).
Through the instrument mechanisms of the types of permits mentioned above, individuals, business entities and cooperatives may conduct mining business activities in accordance with the business permits filed and approved by authorized officers, therefore in the event of any activities of the exploitation of Minerals and Coal which do not possess or hold a license the business mentioned above, can be categorized as illegal mining criminal act (PETI) as explicitly regulated in:

1. Article 158 of the Minerba Act stipulating that any person undertaking a mining business without IUP, IPR or IUPK shall be liable to a maximum imprisonment of 10 (ten) years and a maximum fine of Rp10,000,000,000.00 (ten billion rupiah).

2. Article 160 which regulates:

a. Any person conducting exploration without IUP or IUPK as referred to in Article 37 or Article 74 paragraph (1) shall be sentenced to a maximum imprisonment of 1 (one) year or a fine of not more than Rp200.000.000,00 (two hundred million rupiah).

b. Any person who has an Exploration IUP but conducts a criminal production operation with a maximum imprisonment of 5 (five) years and a maximum fine of $\operatorname{Rp~10,000,000,000.00~(ten~billion~rupiah).~}$

Referring to data of handling of unlicensed mining criminal case handled by Polri (Data source: Criminal Investigation Police) writer take random data that at the end of January 2016 there are 26 me mbers of mining community of excavation C kecamatan Patimbak Deli Serdang Su matera Utara illegally processed by Resort Police Deli Serdang. Then data at Polres Bogor in 2016 has arrested 22 illegal gold miners operating in the area of PT Aneka Tambang Persero Tbk. Mount Pongkor. Data handling cases by Police Way Way Lampung has been processed as many as 21 people who conduct illegal gold mining activities because they do not have a mining permit. There is also the handling of unlicensed mining cases handled by Police Station of Kuantan Sangingi Polda Riau based on data of 2015 in Jambu Island Kec. Sangingi there are 25 people to be processed and in the bayur is land 30 people are designated as a suspect for undertaking gold mining activities without permission. Furthermore, Bangkabelitung Regional Police in 2010 handled 24 illegal mining cases. While based on data at the Ministry of Environment[8] in 2015 there are thousands of PETI locations involving 2 Million miners, with groupings into 12 findings of $22 \%$ PETI in gold mining, $3 \%$ PETI on granite and quartz stone mining. In terms of equipment there are $57 \%$ using mechanical equipment and $43 \%$ using manuals, viewed from active dominant $84 \%$ state status, $16 \%$ inactive, viewed from $31 \%$ state land status, $2 \%$ conservation forest, $9 \%$ protected forest and $6 \%$ production forest. From the perspective of economic prosperity, the perpetrators of PETI showed that $77 \%$ had improved welfare, and only $2 \%$ experienced a decrease in welfare, then in the age of 32 PETI perpetrators were 36 children and 53 women and elderly perpetrators.

Based on data of perpetrators of illegal mining crimes (PETI) in terms of socioeconomic level of perpetrators can be seen that the perpetrators of PETI above is a local group of marginal groups who rely their lives from mining activities without permission, then based on data from the Ministry of Environment above that year 2015 there are 
thousands of PETI locations and involving 2 million miners, where in terms of socioeconomic aspects of PETI perpetrators there is $77 \%$ benefit of increased welfare or equivalent to 1.540 .000 miners get increased welfare from mining activities without permission. On the other hand, the mining actors are categorized as illegal mining crimes that must be upheld also in the perspective of law enforcement.

The problem of law enforcement in the perspective of PETI is not solely on the aspect of law enforcement alone, but in this matter it is considered important to consider the sociological aspects, economic justice and philosophy of PETI perpetrators, since the perpetrators of this PETI are mostly or almost entirely small-scale miners, it would be fair if the PETI miners who belong to this small scale category get special treatment and not merely prioritize law enforcement only for the purpose of realizing legal certainty and can impact the ineffectiveness of law enforcement because of conflict of interest between juridical interest and the interest of justice and benefit or in other words there is a conflict of interest between textual and legal contextual.

\section{PROBLEMS}

1. To what extent are the interests of illegal mining law enforcement (PETI) with sociological, economic and philosophical interest in the perspective of legal justice?

2. What is the policy solution for law enforcement of unlicensed Minerals and Coal Mining activities by s mall scale miners?

\section{RESEARCH METHODS}

The approach used in this study is the socio legal reseacrh approach that entered the type of qualitative research, where the approach used is an alternative approach that examines the doctrinal study of the law, which word socio in social legal studies represent interrelationships between the context where the law is located, so that the theory use is a social theory for the purpose of analys is but, it does not mean aiming to give attention to social science alone, but still focus on law and study law[9].

This socio legal research method has kerakteristik in 2 forms, namely:

(1) Undertaking a textual study, ie the study of articles in laws and policies and then analyzed critically to explain the meaning and implications of legal subjects, including marginalized groups or marginal groups, in this case small-scale mining groups with analyze the regulation gradation from the start of the highest regulation to the operational implementation regulations.

(2) Socio legal study by developing new methods which are a mixture of legal and social science methods [10].

In this research, the writer will conduct a textual study in the form of study on Article 158 and 160 Minerba Law to be tested for its validity to illegal mining actors (PETI) which in its implementation confronts law enforcers in a dilemmatic condition between the interests of illegal mining law enforcement (PETI) sociological, economic and philosophical interests in the perspective of legal justice. The data used in this assessment is law enforcement that has been done by the investigators from the Police taken sampling and data from the Ministry of Environment, as well as data from interviews by the authors during the field observation at PETI mountain location in Pongkor Bogor. Furthermore after the data collected and then conducted a qualitative analys is prescriptive in terms of 3 aspects of activities, namely data reduction, data presentation and conclusion.

\section{DISCUSSION}

\section{A. Background ofUnlicenced Mining}

\section{1) Regulatoryfactors}

The background of the unlicensed illegal mining by marginalized group of people who entered in the small scale type one of them is also caused by the problem of regulation that causes occur in law making process that is the existence of legal norms problematic in its formation which eventually cause problems also in its implementation. Some of these regulatory is sues underlying the occurrence of PETI among others related to the problem:

\section{No operationalization oflegal norms in the Minerba Act.}

There are several legal norms in the articles of the Minerba Act, among others, provided for in article 58 which are not operational "stipulates that in relation to the issue of a five-hectare area boundary to apply for exploration mining permits for rock commodities". This article poses a problem for an IUP applicant whose area is less than 5 hectares, where technically a lot of rock mining is less than 5 hectares, such as sand mining commodities, sand mining co mmodities, limestone and other mines.

Apart from that, as in Article 36 of the Minerba Law regulating the IUP consists of two stages: exploration IUP covering activities of public interest, exploration and feasibility study, and secondly, IUP production operations include construction, mining, processing and refining activities, as well as transportation and sales. In Article 36 paragraph 2 of the Minerba Law even though it is stipulated that the holders of exploration IUP and IUP of production operations may undertake part or all of the activities but in Article 36 of the Law it shall continue to stipulate that all mining business activities shall undertake the stages of exploration and production operations, in part or in all activities, in fact there are some mining commodities, especially rocks that do not require these stages, so this provision becomes not operational.

The background of the provisions in the Minerba Law articles above which caused certain mining commodity miners cannot apply for mining business permits due to nondilatable rules. While on the other hand, people consider there is a mining commodity around the area that can be cultivated in order to provide prosperity for them, and this is the condition that encourages and causes people around the mining area to conduct illegal mining practices (PETI) and this background is directly unlicensed mining crime.

Whereas even though the Minerba Act has accommodated the IPR consent scheme which has the characteristic of granting permits to the local people and the small area of less than one hectare (for individuals and groups) and at most 10 hectares (for cooperatives) as mandated in article 68 Mining Law. Article 69 of the Minerba Law explicitly states that the holders of IPR are granted rights, namely: the right to receive guidance and supervision in the field of occupational safety and health, 
environment, technical mining, and management of the government and / or local government and receive capital assistance in accordance with legis lation.

Whereas in practice the above mentioned regulations are still found to be constraints related to the provisions of IPR as regulated in Article $48 \mathrm{PP}$ No 23 of 2010 governing to obtain the IPR of the applicant must be eligible: (administrative requirements, technical requirements, and financial requirements)[11].

Although the requirements appear to be simple, there is one requirement concerning technical requirements that are not easy or difficult to fulfill by the people miners as stipulated in article 48, paragraph 2 letter b, which is in the form of a statement concerning: (in the form of a summit on the most IPR within 25 meters; mechanical, milling or machining pumps with maximum power of 25 horse power for one IPR and not using heavy equipment and explosives), so the requirement becomes irrelevant to the people's mining concession, considering that at this time the people's mining area has many potential areas which is deeper than 25 meters, which must use mechanical pumps, and a milling or machining with more than 25 horsepower, and must use explosives.

\section{2) Licensing Bureaucracy Capacity Factors}

That the principle of public service including the licensing service requires the government to establish clear, detailed, detailed, and measured checking procedures as per Varsha Venugopal 's opinion. for correction, as well as create regulatory uncertainty ". The licensing authority quotes from the opinion of Erique Ortega girones "that licensing around mineral and coal mining is a controlling instrument. The licensing issue is caused by the provision of mining business licenses and licenses that have an economic impact, so the Ministry of Energy and Mineral Resources has conducted a reconciliation of the data on the national mining business permit which is intended to create coordination, verification and synchronization of IUP in all provisions / districts / cities in Indonesia, the availability of mineral IUP data nationally well and expected to increase state revenues and at the same time it is expected to be the integration of central and regional IUP data [12]. The background of problems in licensing capacity both concerning aspects of institutional capacity and human resource capacity that certainly impact on non-reformist capacity indirectly can impact the psychological attitude of small miners not to apply for permits and will choose unlicensed mining for reasons expensive, difficult, long and no certainty [13].

\section{3) Nomative Coaching and Supervision Factors}

In Government Regulation No. 55 of 2010, there is no provision for the development of small miners, which in the present regulation prefers the criminal law enforcement aspect to local communit ies of miners without permits which have no room to treat PETI perpetrators with a persuasive approach, such as whitening such activities to become a legitimate business through a coaching approach.

\section{4) Factors of Law Enforcement Obstacles}

Considering that the unlicensed miners commit the crime or their actions not only concerning the dimensions of the crime but since the perpetrators are some marg inalized local people and entering the small-scale miners category, a fair policy must be adopted through coaching mechanisms from the mining agency and providing special treatment in the granting of mining permits, so that in the case of law enforcement, this law enforcement measures as a last resort or Ultimum Remedium.

\section{5) Socio-Economic Factors}

Based on the results of research from Mark L Wilson that globally over one hundred million people of their lives depend directly or indirectly on s mall-scale mining activities, whereas in Indonesia the existence of several smallholder mines has existed long before the country became independent and this small-scale society has been hung his life as a source of income for the people of the miners from mining activities for generations and considering some problems related to the above mentioned permits that encourage unlicensed mining activities [14].

\section{B. Impact of Unlicensed Mining Activity (PETI)}

Unlicensed mining activities may have some impacts such as:

\section{1) Impact of environmental damage;}

PETI activities such as gold mining in Mount Pongkor, Bogor use mercury that exceeds the threshold in the management of gold in the form of gold, in addition to impacting the actors through the air and metabolism in the food chain, and mercury levels found in Mount Pongkor reached 18 milli grams per $1 \mathrm{~kg}$ or 36 times of the standard and has become a mutual symbiosis between the need for minerals and the incomes of society even if it has to hurt the environment and human health, where the use of mercury and cyanide is common.

\section{2) Impact of state revenues}

PETI activities are of course not recorded by the government on the legality or outcome of the mining activities of the PETI actors, so that the perpetrators of PETI become irrespective of the obligation to pay taxes, as the opinion of Cut Dian Agustina "The Government revenue from mining comes mostly from royalty and land rent. Royalty taril is expressed in percentage terms and varies according to the mining scale, production level, and commodity. The royalty is calculated by the sale price and the taril[15].

\section{3) The impact of social conflict}

Referring to data released by the Ministry of Environment and Forestry, there are 84 sites based on field verification of 302 PETI locations there are social conflicts both between immigrants with local residents or both local residents and between citizens with the apparatus, such as the case which once scandalized the killing of Salim Kancil in Lumajang conducted by unscrupulous villagers.

\section{4) Occupational health, safety and security impacts}

Mining activities are certainly at high risk due to its insecure location plus the use of mercury and cyanide as a necessity in the PETI activities which in practice this PETI activity ignores the safety aspect of work.

\section{PETI Law Enforcement Policy Solutions}

\section{1) The necessity of The Greatest Happiness of The} Greatest Number Principle

That is the principle attached or unify the formulation of prosperity for the community on the other hand with the interests of law enforcement by promoting happiness / happiness with the interests of law enforcement[16]. Based 
on the theory of Betham Kesenangan (kemanfaatan) in question is the benefits that terpositifkan in a rule (law) which has 4 (four) functions: "to provide subsistence; to produce abudance; to favor equality; and to maintain security ". From Bentham's legal function, when associated with PETI, mineral and coal mining enterprises including those which are illegally must be able to provide "livelihood", "welfare", "equality", and "security", so that the existing PETI sociologically must given the instrument to conduct its mining business activities legitimately (normative juridical).

Bentham theory, the authors agree that the problems related to PETI can be solved through a regulatory reformulation policy that accommodates PETI become legal and licensed miners through the mechanism of coaching from relevant agencies as well as the application of strict supervision so that PETI does not occur and miners who have metamorphosed into legal and licensed miners good mining practices.

\section{2) Ultimum Remedium (as Criminalism Policy)}

In the event that the government will enforce the law or the law enforcers will criminalize, it becomes important to prioritize policy in order to keep the ultimate argument of remediu $m$ so that there is no over criminalis $m$ as the opinion of G. Pieter Hoenagels, namely: the application of punishment not in an emotional way; punishment must be against the perpetrator and the clear and measurable elements of both the victim and the loss; in order for the decision of punishment to be considered the comparis on between the losses incurred and the punishment so as to ensure that the loss must be greater than the cost of criminalization; do not use criminal law if it does not have strong legitimacy from the community; do not criminalize if its use is not expected to be effective; Criminal law in certain matters should consider specifically the priority scale of regulatory interests; Criminal law as a repressive means must be utilized simultaneously with prevention means [17].

Furthermore, as stated by Barda Nawawi Arief that criminal policy is inseparable from broader policy, namely social policy consisting of policies / efforts to social welfare (social welfare policy) and policies / measures to protect people (social defense policy)[18]. (Barda Nawawi Arif, 2008:77)

Referring to the fact of the existence of social welfare policy and social defence relationship, it is important to consider as pects outside of penal (penal) through non-penal approach. The non-penal approach can be done through techno prevention approaches; prevention and crime prevention by technology, cultural approach through development and community sensitivity generation including law enforcement apparatus, or moral education approach, or global approach that is through international co-operation and bureaucratic approach [19]. Based on the facts of the phenomenon above it becomes important to take a special punishment policy on unlicensed mining crime by prioritizing non penal aspects through guidance and supervision, consultation and facilitation of granting of business license both IUP and IPR which accompanied by environmental processing, management of exploitation and marketing aspect so that miners of PETI are expected to continue their business and their enforcement actions through non-penal approach and the achievement of PETI's activity goal can stop and become legal mining act.

\section{CONCLUSION}

Unlicensed mining activities under the criminal category subject to violating articles 158 and 160 of the Minerba Law involve multi-dimensional aspects not merely criminal matters but also related to the livelihoods of marginal local people who rely on unlicensed mining activities. That the occurrence of unlicensed mining action is caused by several factors, among others, regulatory problem factors; bureaucratic licensing capacity factor; coaching and supervision factors; factors of law enforcement and socioeconomic factors. PETI activities have a negative impact such as the impact of environmental damage; impact of state revenues; the impact of social conflict; health impact; occupational Health and Safety. The crime policy applies the principle of the greates happiness of the greate number principle and the criminal punishment policy as ultimum remedium.

\section{ADVICE}

It's suggested that the policy of PETI settlement is based on cost and analysis to pursue the greatest happiness of the greatest principle and wiser mining activities. Virtue by law enforcement and apparatus promotion towards non-penal policies through techno prevention through small scale guidance and supervision mechanism so that principals will comply with the laws and their mining act to be legitimate.

\section{REFERENCES}

[1] (Iwan Azis, Lidya M, etc: 2010: 22)

[2] (United Nation Environment Programer, By Drexhage and Deborah Murphy: 2012:15)

[3] (No:001-021/PUU-I/2003)

[4] (Draxehage and Deborah Murphy, 2012:41)

[5] (Constitutional Court Decision no: 36/PUU-X/2012)

[6] (Article 1 Pharagrap 7, 8, 9 Law No 4 of 2009)

[7] (Article 8, Article 1 pharagrap 10,11)

[8] http://industri.bisnis.com/read/20151208/44/499545/tambang-ilegalkementerian-lingkungan-menemukan-buruh-anak-kematian-hinggakonflik

[9] (Banakar and Travers, 2012:3)

[10] (Sulistiowati Irianto, 2011:5-6)

[11] (Article 48 pharagrap 2, Government Regulation no 23 of 2010)

[12] (Varsha Venugopal, 2014:3).

[13] (https://www.esdm.go.id/id/media-center/arsip-berita/koordinasipendat aan-izin-usaha-pertambangan-nasional-2011)

[14] (Mark L. Wilson, 2015:8134)

[15] (Cut Dian Agustina, 2012:7)

[16] (Bentham, 2011:29)

[17] (G. Pieter Hoenagels, 1963:231)

[18] (Barda Nawawi Arif, 2008:77)

[19] (Barda Nawawi Arif, 2006:90) 